\title{
Determinants of Liquidity and Market Risk and the Effect on Bank Performance in Bahrain and Malaysia Banking
}

\author{
Norazwa A. Zolkifli, Khairul Jannah Samsudin, and Mohd Burhan Yusof
}

\begin{abstract}
This paper examines the determinants of liquidity and market risk of conventional and Islamic banks for two countries; Malaysia and Bahrain and the effect of the determinants on bank performance. Data were collected from 2008 to 2016 and analyzes using panel data analysis. The results reveal that bank capitalization and interest rate are significant determinants of liquidity and market risk respectively in both countries. In addition, banks capitalization and non-interest income/income attributable significantly affects performance in both banking system. The findings of this study among others can assist the banks in complying with the existing guidelines on risk management and supervision provided by the Basel Committee on Banking Supervision and Islamic Financial Services Board. Instead of that, this result also can coordinating technical and vocational education and training development with government departments responsible for trade and industry especially in banking system, workplace relations, and science and technology, to align skills being taught with government policy directions.
\end{abstract}

Index Terms-Bank performance, liquidity risk, market risk, Islamic bank, conventional bank.

\section{INTRODUCTION}

In modern theory of financial intermediation, bank exist in the economy to facilitate flow of funds in the economy, thus banks play very significant roles in the economic development and are the main stimuli of economic progress. Therefore, the effectiveness and the efficiency of banking services are vital to ensure the smooth running of the fund flow, hence the stability of the financial market and the economy. [1] provide evidence that efficient and effective performance of banking guarantees the financial stability of a country. Thus bank performance is critical for its survival. Studies that examine determinants affecting the bank performance, such as [2], do not clarification concerning the bank risk determinants existed in relation to performance.

In exercising effective and efficient role as financial intermediation in current competitive and dynamic financial market, banks are vulnerable to risks. As stated by [3], emerging market financial systems are less resilient than the banking systems of developed countries. On the importance of risks, [4] highlight that liquidity risk and market risk are considered an important internal determinants of bank performance because it can be a source of factors on bank failure. Performance was influences from various risks is that

Manuscript received May 15, 2018; revised January 5, 2019

The authors are with the Polytechnic Sultan Idris Shah, Sg Lang, 45100 Sungai Air Tawar, Selangor, Malaysia (e-mail: norazwa76@gmail.com, khjannah.samsudin@gmail.com,mohd_burhan@psis.edu.my). risks are related to each other and it also very impossible to completely separate different types of risk to examine the bank performance. Market risk can affect of changes in interest rate and value of foreign currency position on bank performance for a develop country [5]. In banking activities, such as borrowing short term and lend long term, bank will be exposed to reprising and yield curve risk because of their interest rates are not fully flexible. Hence, the short term interest rate and performance had a negative relationship and mostly been offered by the literature such as [6] and [7]. If market parameter such as currency rate will increase, it will reduces the value of bank portfolio assets and it will creates the market risk. Nevertheless, with the higher currency rate it can lower the value of bank cash assets and market risk will rise and this will give the impact to the performance.

Liquidity risk also should be given proper consideration and it will give impact on performance to the banks. During the financial crisis in 2008-2009, liquidity was a key factor because bank funding sources will dried up quickly and short on cash to cover their obligation as they came due [8]. In fact of that, policymakers have suggested that bank should hold more liquid asset to help self-insure toward potential liquidity difficulties. Liquidity assets generally have relatively low income and will impose an opportunity cost on a bank. These are reasonable to expect that banks will hold liquidity assets that can increase their profitability. The dilemma that faced by banking industry can increasing profit at the cost of liquidity will bring a serious problem to the banks [9]. For this reason liquidity risk needs to be monitored as a part of risk management process to ensure stability and dynamic management that can affect performance in banking industry.

The focus of this study on both Islamic and conventional bank is to consider the unique duality banking system in Malaysia and Bahrain. Literatures have provided differences between the two systems, one of it is that Islamic banks has a limited number of financial instruments that restrict them to be endowed with maturities of their deposit and loans through recourse to money or capital markets. To relate this aspect on the issue of risks, [10] discover that the insufficient liquidity instruments to comply with Islamic law increase bank liquidity risk. In order to stay competitive in the growing environment of the banking system, Islamic bank should provide more alternative products to comply with customers' demand at any time. With limited acceptable financial instruments offered in the market, Islamic banks are facing with limitations in raising funds aggressively. Hence, they do not have the same funding options as conventional banks. For market risk, these banks maintain their performance through their ability to overcome losses caused by market risk by relying on the capital and reserves. The admissible threshold market risk should not exceed the potential unexpected losses 
or unfavorable changes, which the bank can assume without disturbing its financial stability. Moreover, the Basel Committee on Bank Supervisory (BCBS) and Islamic Financial Services Board (IFSB) has implemented risk management guidelines to shape the banking industry. Thus, market risk should be managed together with liquidity risk and eliminating one of the risks will create another new risk in the banking system.

\section{LITERATURE REVIEW}

Studies on determinants of risk and bank performance are widely covered by the past researcher. Most of these studies have examined on the determinants of banking risk such as liquidity, market, credit and operational risks in a separated research. But this paper tries to fill the gap by covered determinants of liquidity and market risk together with performance. The effects of risk on bank performance have been widely examined. But there is no empirical study that deals with the same issues addressed in this paper for Islamic and conventional banks or those in other areas of the world. There is vast empirical studies deal with only one type of risk on performance, but studies by [5], [11]-[13] address more than two types of risk affected on performance.

Study by [13] that examines the determinants of majors risk faced by both Islamic and conventional banks, and the relationship between different risks and bank performance for Gulf Cooperation Council (GCC) countries founds that only conventional banks have a significant with the liquidity risk. The first reason is the policy of central banks regarding lending against interest had a conflict with Islamic banks' code of ruling out interest for borrowing and lending. Hence, banks are unable to diversify the risk. [14] discover that Islamic banks have more liquidity risk as compared to conventional banks because of the availability of an Islamic Money Market and central bank regulation on capital and liquidity requirements for Islamic banks. This is happen in Malaysia that banks engaging in Islamic financing have lower liquidity risk but have a higher interest rate risk in conventional banks. This is because considering the existing market positions that are dominated by conventional banks and Islamic banks cannot neglect the market interest rate. One type of market risk faced by Islamic banks is profit rate risk and it equivalent with interest rate risk for conventional banks. However, the main cause for interest rate risk exposure is volatility of interest rate in the market. As a result, the profit margins of the conventional bank will not affected. This shows that liquidity and market risk have a significant relationship on performance in Islamic and conventional banks.

According to [12], optimized combination of exchange portfolio or the state of each exchange in international market, the financial institution such as banking sector will imposed huge losses for banks. Therefore, risk and performance have a key role and future events are not fully predictable for some events are preferable to other events. The impact of risk factor on financial performance of banks is undeniable and for this reasons it potentially can affect on financial decisions. This result found that market risk and the related indicator are significantly affected on performance. [5] found that market risk have a positive and significant effect on performance that measured by bank stock return volatility. The possible explanation of the positive relationship between market risk and performance that bank may not hedge their risk exposure well by using financial instruments known as derivatives. This result was consistence with [7] that investigates the effect of interest rate and foreign exchange rate charges on Turkish banks' stock on performance.

Ref. [11] examined liquidity risk and performance in Islamic banks. They found that liquidity risk has no significant on performance but [15] found that liquidity risk were highly significant in affecting performance. The results indicate a good performance in Islamic and conventional banks covered, measured by return on asset and equity. Liquidity risk is consider as one of the serious and challenges for the modern banking. With the good asset quality, a strong earning and sufficient capital may fail because of not maintaining adequate liquidity in the proper manner. At the end, to establish the relationship between liquidity risk and performance must be sought. In fact of that with a significant liquidity gap, the banks may have to borrow from the repo market at a higher rate rather than pushing up the cost of banks. Result by [16] was consistence with [15]. This is show that liquidity risk is the most important risks facing both Islamic and conventional banks [17].

In regards to the determinants of liquidity risk, interbank ratio (IR) is one of the factors that may affect liquidity risk. It is the interest rate charged on short-term loans made between banks. This rate depends on the existence of money in the market. According to [18], if the interbank ratio is high, it will increase risk to the bank. Thus support that interbank ratio may be used to evaluate bank performance and dependable on the financing obtained from the institution or from other banks.

Other studies have argued that loan volatility could influence liquidity risk. This relate to the fact that liquidity problem occurs when there is a lack of commitment given by the borrower to withdraw deposit and normally, long term profit is always influenced by long-term loans. Thus, high loan volatility (LVOL) will increase the liquidity risk that can cause unexpected loans. Higher uncertainty in financing or loan will reduce the ability of the bank to meet the excessive loan demand. According to [19] LVOL has a positive relationship with liquidity risk in Islamic and conventional banks. This is supported by [20] and [21] who have similar opinion in which they find out that the higher the loan, the higher the liquidity risk is.

Another factor that may influence liquidity risk is bank capitalization (CAP). Bank capital is a difference between the value of the assets and the value of the liabilities of the bank that represents the net worth of the bank or the value to investors. In terms of the capital standard, banks must hold the capital that commensurate with the amount of credit risk, and which will influence the size of the loan portfolio [21]. However, according to [20] capital in banking system increases the trust of depositors and indirectly reduces the liquidity risk. Moreover, an increase in bank's capital may reduce problems occurred in loan portfolio and thus may raise loan to deposit ratio. As stated by [19], if depositors have to insure their loans they can influence the changes in the level of capital if they are the majority of the depositors, thus supported the effect of the loan portfolio capital 
dominated by extensive number of depositors. Hence, studies by [19]-[21] indicate that bank's capital has a positive relationship with liquidity risk.

Loans to deposit ratio (LD) has also been identified as one of the determinants of liquidity risk. There are studies that argue a low LD ratio indicates that bank has less resources of fund. According to [18] if LD increase, exposure to the larger deposit could not be fulfilled. These results are also supported by [19] found that a low LD can guarantee the bank in having sufficient funds to meet the large withdrawal by depositors as well as unexpected loans. Thus, LD has a positive relationship with liquidity risk.

In order for banks to maintain a high level of growth, they should have a high growth of total asset (GTA). This is another factor that has been used to reflect the liquidity situation in banking system. The banking is considered safe when GTA is at a high level. According to [19] any increase in GTA can directly increase the expected income and the estimated of financial cost will be reduced. Similarly, [13] find that GTA and liquidity risk have a positive relationship. Discussion on banks' total asset normally will relate to the banks' management efficiency (MGT). However, in contrast to GTA, MGT may have negative relationship with liquidity risk since efficiency can help banks to achieve a balance in liquidity funds needed to invest and obtain the high returns to meet the requirements of the deposit. This implies that if MGT is at a high level, liquidity risk can be reduced.

Bank size has been much discussed by previous researchers on liquidity risk but less discussed on market risk. [22] examines the connection between liquidity and reduction of bank portfolio in the financial system without having deposit insurance in Japan and find a positive relationship between size of banks and liquidity. This shows that banks are typically sized to hold more loans and have a larger gap of financing and this is one of the problems with liquidity in banking. Examining similar issue but focusing on Islamic and conventional banks, [23], [24] find that liquidity risk management is different between Islamic and conventional banks in Pakistan. They find that size of the bank and liquidity has a positive relationship. Similar finding by [25] find that both variables have a direct relationship for commercial banks in Pakistan. While other studies such as [20], [26]-[28] supported the positive relationship between size of the bank and liquidity, other group studies such as [13] and [10] find a negative relationship between these two variables. According to [29], bank size (SIZE) is only significant with implied asset risk and total risk exposure. This shows that SIZE is significantly related to market risk.

Studies on this issue have also used data from Islamic banks among others by [13], [19]-[21]. [20] who studies three types of bank risks that have an effect on Islamic banks reveals that high deposit volatility (DEPVOL) has high exposure on liquidity risk. Therefore, high uncertainty of deposit will reduce the ability of the bank to make a withdrawal. Similarly, [13] and [21] also find that Islamic banks with high DEPVOL reduce the liquidity of banks thus lead to increase in liquidity risk, strengthening on the claim that high deposit volatility increases the liquidity of the bank. In contrast, [19] find that DEPVOL has a negative relationship with the liquidity risk in Indonesian conventional bank.

In regards to the determinants of market risk, studies have also show that they are influenced by bank specific factors as well as macroeconomic factors. One of the factor is total loan/financing, which has been examined by studies such as [30]-[34] focusing on the linkage between lending structure and market risk exposure and provide evidence that total loan expansion (TL) has a positive significant relationship with market risk. These results conform to prior belief on the positive association between loan expansion and bank risk exposure. On the aspect of management efficiency, [34] in a study regarding lending structure and market risk find that MGT has a significant negative relationship with market risk in which contradicts with the study by [35] who finds that Malaysian banks are efficient in terms of managing its risk exposure particularly in relation to market fluctuation.

A study by [13] regarding risk exposure of Islamic financial institutions using interest rate risk from Gulf Co-operation Council countries shows that there is a significant relationship between non-interest income (NONII) and interest rate risk. Interest rate risk is considered a kind of market risk and is a probability that variation in interest rate will have a negative influence on the quality of portfolio in banking. This shows that firms with lower NONII will have lower market risk. Their study also finds that interest rate ration (GAP) has a significant negative association with interest rate risk for conventional banks. Total asset will increase due to short term funds to provide long-term loans and GAP will increase the profit and decrease the exposure of interest rate risk. On the other hand, market risk has a positive relationship with NONII and negative significance association with GAP.

Previous studies have also examined the regulatory restrictions on bank risk-taking; [33] finds that high investment (INV) in consolidated can represent a loss of diversification; hence it should be responsible for a higher risk exposure. This shows that INV are also related to market risk exposure in the banking system. [34] notes that short-term investment (INV) can be categorized into three types: securities held for trading, securities held for maturity and securities available for sale. The obvious difference between conventional and Islamic banks is that in terms of securities held for trading. The above discussions suggest that banks' liquidity and market risk can be determined both by bank specific factors such as size of the bank, profitability, capital adequacy, and asset management as well as macroeconomic factors such as interest rates and interbank ratio.

\section{RESEARCH DESIGN AND METHODOLOGY}

\section{A. Research Methods Overview}

The main objective of this study is to investigate bank specific determinants of liquidity and market risk and then to analyze the effect of these determinants on bank performance for Malaysia and Bahrain. The samples consist of time series and cross-sectional data of selected Islamic and conventional banks from year 2008 to 2016 . The data used in this study is collected from annual reports of each bank. The sample comprises of 37 Malaysian banks and 30 Bahrain banks.

In examining the determinants of liquidity and market risks, the dependent variables consist of liquidity risk measured by current asset to current liability and market risk 
measured by earning per share. For the liquidity risk models that used in this study was based on a study made by [13], [19] and [22]. The independent variables are interbank ratio, deposit volatility, loan/financing volatility, bank capitalization, growth of total asset, management efficiency, natural log of total asset (SIZE) and loan/financing to deposit ratio. The selection of these variables for market risk are in line with [36] who identify that four most common factors connected with market risk are interest rate, currency exchange rate, investment cost in trade portfolio and price of exchange commodities. The variables are total loan/financing, total equity, loan loss provision, rate sensitive assets to rate sensitive liabilities ratio (GAP), interest expenses/other overheads and expenditure, short-term investment, bank size, management efficiency and non-interest income/income attributable. One of the objectives of the study is to analyze the effect of these determinants on bank performance. We use return on equity (ROE) as a measure for bank performance. This is in line with previous studies that have widely used $\mathrm{ROE}$ to measure bank performance.

\section{B. Method of Data Analysis}

The Generalized Least Square (GLS) analysis is carried out in order to determine the coefficient for each variable using Fixed Effect Model (FEM) and Random Effect Model (REM). To choose which model is the best, Hausman test is used. This test is theoretically performed to select whether FEM or REM is to be used in the panel data analysis. This paper incorporates time series and cross section weight in the
GLS estimation because the data is not normally distributed. According to [37], GLS method helps to reduce heteroskedasticity issue; hence it is the most appropriate method compared with ordinary least squares (OLS). The research has the following general model:

$$
Y_{i t}=\alpha_{0}+\Sigma X_{i t}+\varepsilon
$$

where,

$Y_{i t}=$ dependent variable (bank performance) for bank $i$ at time $t, X_{i t}=$ independent variable (determinants of liquidity and market risk) for bank $i$ at time $t, \alpha_{0}=$ constant and $\varepsilon=\eta_{i}+$ $\mu_{i t}$

Then (1) is extended to include all explanatory variables for the research model as follows:

\section{Model 1}

$\mathrm{LR}_{i t}=\alpha_{0}+\beta_{1} \mathrm{IR}_{i t}+\beta_{2} \mathrm{DEPVOL}+\beta_{3} \mathrm{LVOL}_{i t}+\beta_{4} \mathrm{CAP}_{i t}+\beta_{5}$ $\mathrm{LD}_{i t}+\beta_{6} \mathrm{GTA}_{i t}+\beta_{7} \mathrm{MGT}_{i t}+\beta_{8} \mathrm{SIZE}_{i t}+\varepsilon_{i t}$

\section{Model 2}

$\mathrm{MR}_{i t}=\alpha_{0}+\beta_{1} \mathrm{TL}_{i t}+\beta_{2} \mathrm{LLP}+\beta_{3} \mathrm{TE}_{i t}+\beta_{4} \mathrm{GAP}_{i t}+\beta_{5}$ $\mathrm{INTEXP}_{i t}+\beta_{6} \mathrm{INV}_{i t}+\beta_{7} \mathrm{SIZE}_{i t}+\beta_{8} \mathrm{NONII}_{i t}+\beta_{9} \mathrm{MGT}_{i t}+\varepsilon_{i t}$

Result from model 1 and model 2, model 3 will develop to investigate which factors are significant with performance.

Model 3

$$
\mathrm{ROE}=-f(\mathrm{LR}, \mathrm{MR})
$$

TABLE I: DESCRIPTIVE STATISTIC FOR CONVENTIONAL BANK

\begin{tabular}{lcccccc}
\hline & \multicolumn{3}{c}{ Malaysia } & \multicolumn{2}{c}{ Conventional bank } & \multicolumn{3}{c}{ Bahrain } \\
\hline Variable & Mean & Median & Standard Deviation & Mean & Median & Standard Deviation \\
\hline LR & 1.1569 & 1.0940 & 0.2684 & 1.2950 & 1.2543 & 0.6807 \\
MR & -0.5326 & -0.4834 & 0.4142 & 0.4514 & 0.3944 & 0.5011 \\
ROE & 0.4931 & 0.5150 & 0.2451 & 0.1716 & 0.2021 & 0.2861 \\
IR & 0.3793 & 0.2431 & 0.7745 & 0.8801 & 0.8126 & 0.7724 \\
DEPVOL & 0.3890 & 0.4543 & 0.1670 & 0.6069 & 0.7127 & 0.3367 \\
LVOL & 0.0678 & 0.0738 & 0.0311 & 0.1843 & 0.2094 & 0.1269 \\
CAP & 0.1116 & 0.0921 & 0.0569 & 0.1840 & 0.1337 & 0.1315 \\
GTA & -0.0905 & -0.0681 & 0.1955 & -0.1468 & -0.0232 & 1.1658 \\
MGT & 0.4312 & 0.3593 & 0.1795 & 0.7936 & 0.9123 & 0.2994 \\
SIZE & 7.3933 & 7.6055 & 0.6733 & 3.0156 & 3.2473 & 1.3724 \\
LD & 0.6554 & 0.7103 & 0.3504 & 0.5416 & 0.5689 & 0.4350 \\
TL & 0.5111 & 0.5971 & 0.2274 & 0.3740 & 0.4203 & 0.2440 \\
LLP & 0.1988 & 0.1380 & 0.1891 & 0.0043 & 0.0023 & 0.0073 \\
TE & 0.1113 & 0.0921 & 0.0525 & 0.1840 & 0.1337 & 0.0073 \\
GAP & 0.1246 & 0.1150 & 0.1147 & -0.1482 & -0.2107 & 1.6965 \\
INTEXP & 0.1873 & 0.2360 & 0.2425 & 1.7008 & 0.1776 & 1.2087 \\
INV & 0.1361 & 0.1399 & 0.0662 & 0.2063 & 0.176 \\
NONII & 1.0992 & 0.9274 & 0.7034 & 0.0084 & 0.0080 & 0.1971 \\
\hline
\end{tabular}

\section{EMPIRICAL RESULTS AND DISCUSSION}

\section{A. Descriptive Statistic}

Table I and Table II presents the descriptive statistics related to determinant of liquidity risk (LR), market risk (MR) and performance (ROE); Interbank Ratio (IR), Deposit Volatility (DEPVOL), Loan Volatility (LVOL), Capitalization (CAP), Growth of Total Asset (GTA), Management Efficiency (MGT), Bank Size (SIZE), Load to Deposit Ratio (LD), Total Loan/financing (TL), Loan Loss Provision (LLP), Non-Interest Income (NONII), Short-term Investment (INV), Total Equity (TE), Ratio of rate sensitive asset to rate sensitive liabilities (GAP), Interest Expenses/other overhead and expenditure (INTEXP). These statistics include mean, median and standard deviation. The finding shows that banking system in Malaysia and Bahrain differs in terms of liquidity and market risk. Islamic banks in Bahrain recorded the highest mean liquidity risk of 1.833 over the study period. The next highest liquidity risk is conventional banks in Bahrain (1.295) followed by conventional banks and Islamic banks in Malaysia of 1.156 and 1.069 respectively. The results also show that the highest mean in market risk of 90 per cent is from Islamic banks in Bahrain followed by Islamic banks in Malaysia (83\%), conventional banks in Malaysia (53\%) and conventional 
banks in Bahrain (45\%). In terms of performance (ROE) the highest mean return on equity is Malaysia Islamic banks $(59 \%)$. Conventional banks in Bahrain experienced a lower level of mean return on equity of 17 per cent. Descriptive statistics in Table I and Table II also shows that the highest mean on the determinants of liquidity risk, market risk and performance are from conventional banks in Bahrain and Islamic banks in Malaysia. The results suggest that these banks may have different determinants on their bank risk. In addition, the results show that variable with the largest standard deviation among banks is short-term investment (INV) from Islamic banks in Malaysia. The standard deviation in interest expenses/ is noted also as the highest among all banks. This suggests marked differences in expenses among Islamic and conventional banks.

TABLE II: DESCRIPTIVE STATISTIC FOR ISLAMIC BANK

\begin{tabular}{lcccccc}
\hline & \multicolumn{2}{c}{ Malaysia } & \multicolumn{3}{c}{ Bslamic bank } & \multicolumn{3}{c}{ Bahrain } \\
\hline \multicolumn{1}{c}{ Variable } & Mean & Median & Standard Deviation & Mean & Median & Standard Deviation \\
\hline LR & 1.0692 & 1.0681 & 0.1323 & 1.8330 & 1.3089 & 1.7430 \\
MR & 0.8269 & 0.3873 & 1.2529 & 0.8975 & 0.3985 & 1.6065 \\
ROE & 0.5930 & 0.6122 & 0.2262 & 0.1292 & 0.1085 & 0.1639 \\
IR & 0.3054 & 0.0000 & 1.2034 & 1.1978 & 0.4245 & 2.3170 \\
DEPVOL & 0.4397 & 0.4580 & 0.2416 & 0.3308 & 0.1656 & 0.3490 \\
LVOL & 0.1373 & 0.1231 & 0.0734 & 0.1259 & 0.0604 & 0.1500 \\
CAP & 0.0860 & 0.0760 & 0.0414 & 0.4943 & 0.3763 & 0.3496 \\
GTA & -0.1994 & -0.1605 & 0.2294 & -0.0440 & -0.0029 & 0.2807 \\
MGT & 0.4501 & 0.4155 & 0.1738 & -0.0773 & -0.0545 & 0.0849 \\
SIZE & 7.1525 & 7.0768 & 1.0297 & 0.4114 & 0.4765 & 0.1623 \\
LD & 0.8891 & 0.7881 & 0.7322 & 0.7408 & 0.7401 & 0.0154 \\
TL & 1.8256 & 1.8332 & 0.2369 & 0.2586 & 0.1343 & 0.3004 \\
LLP & 0.0055 & 0.0038 & 0.0080 & 0.0066 & 0.0005 & 0.0164 \\
TE & 8.5043 & 7.5182 & 3.9511 & 0.4964 & 0.3763 & 0.3474 \\
GAP & -0.0795 & -0.0687 & 0.1064 & -0.0695 & -0.0872 & 0.3504 \\
INTEXP & 0.2520 & 0.1262 & 0.3223 & 1.6951 & 0.9003 & 2.8519 \\
INV & 17.936 & 15.3656 & 13.3651 & 0.3172 & 0.2795 & 0.2100 \\
NONII & 1.9191 & 1.9274 & 0.5861 & 2.0430 & 0.3824 & 5.4275 \\
\hline
\end{tabular}

\section{B. Variance Inflation Factor}

In the regression model, due to many independent variables used, the issue of multicollinearity may exist. If independent variables are severely related to each other, the problem of multicollinearity is present. In our study, this problem is detected using Variance Inflation Factor (VIF). Based on [37], the cut-off threshold of 10 is used. Variables with VIF value more than 10 are excluded. The results of multicollinearity diagnostics for each bank's test model are shown in Table III. The results show that there is no multicollinearity problem between the variables. All independent variables are then regressed against liquidity risk, market risk and performance for the whole model.

TABLE III: RESULTS OF VARIANCE INFLATION FACTOR (VIF)

\begin{tabular}{lcccc}
\hline \hline \multirow{2}{*}{ Variable } & \multicolumn{2}{c}{ Malaysia } & \multicolumn{2}{c}{ Bahrain } \\
& $\begin{array}{c}\text { Conventional } \\
\text { bank }\end{array}$ & $\begin{array}{c}\text { Islamic } \\
\text { bank }\end{array}$ & $\begin{array}{c}\text { Conventional } \\
\text { bank }\end{array}$ & $\begin{array}{c}\text { Islamic } \\
\text { bank }\end{array}$ \\
\hline IR & 1.0898 & 1.1643 & 1.8096 & 1.6547 \\
DEPVOL & 2.4597 & 1.7492 & 4.4343 & 2.8342 \\
LVOL & 3.3030 & 2.3524 & 3.3016 & 1.3142 \\
CAP & 2.7204 & 1.6640 & 2.0111 & 1.7229 \\
GTA & 3.5732 & 1.8802 & 2.3198 & 1.4427 \\
MGT & 1.2489 & 1.5432 & 2.2104 & 1.0963 \\
SIZE & 2.1279 & 1.2682 & 3.7816 & 1.2277 \\
LD & 3.9789 & 1.3309 & 2.3410 & 1.9144 \\
TL & 4.1824 & 1.9326 & 2.0838 & 7.5260 \\
NONII & 1.2352 & 1.2389 & 1.1174 & 1.1914 \\
LLP & 1.3013 & 1.2399 & 1.1705 & 1.1470 \\
TE & 3.0816 & 1.4374 & 1.8832 & 5.2120 \\
GAP & 1.5489 & 1.2816 & 1.8606 & 4.7684 \\
INTEXP & 1.6080 & 1.1040 & 1.2022 & 1.2280 \\
INV & 1.2100 & 1.7003 & 1.4837 & 2.9106 \\
\hline \hline
\end{tabular}

\section{Regression Analysis for Liquidity and Market Risk Determinants}

The next step is to conduct a Hausman Test in order to select whether Fixed Effect Model (FEM) or Random Effect
Model (REM) to be used in the panel data analysis. Table IV and Table $\mathrm{V}$ shows the $\mathrm{p}$-value of $\mathrm{Chi}^{2}$ for both models are 0.00 ; below than 0.05 , which means that the model is significant, and the null hypothesis is rejected. Therefore, FEM will be used in this study. This section presents the regression analysis for determinants of liquidity risk and market risk on the performance of the banking system. Generalized Least Square (GLS) method is used in this study. One way to take into account the individuality of each individual bank for each cross-section unit is to let the intercept vary for each bank but still assume that the slope coefficient is constant across banks. In the FEM, the intercept in the regression model is allowed to differ among individuals in order to recognize the fact that each bank, or cross sectional unit, may have some special characteristics of its own. Table VI exhibits the findings on Fixed Effects for model 1 for selected banks. The value of $R^{2}$ shows liquidity risk is explained by the independent variables in which the overall estimation for all banks is good at almost 80 percent or more. From Table VI, the value of adjusted $R^{2}$ is equal to 76 percent for Malaysia conventional banks, 95 percent for Malaysia Islamic bank, 94 percent for Bahrain conventional banks and 86 percent for Bahrain Islamic banks. This value indicates that 76 percent to 95 percent of the total variation in the level of LR in the banks occurs because of the variation in determinants of liquidity risk. This shows that all banks have different risk determinants in both countries. Out of eight independent variables, only six are significant such as LVOL, CAP, LD, GTA, MGT and SIZE. Capitalization (CAP) is significant at 1 percent significance level for all banks and this proved that capitalization is very important to banks to make sure that liquidity risk can be managed in a good manner. On the other hand, the results show that there is no difference between Islamic banks in Malaysia and Islamic 
banks in Bahrain. For both banks, bank size (SIZE) is very significant with liquidity risk at 1 percent significance level and influence liquidity risk positively thus support the finding of Akhtar et al. (2011).

TABLE IV: HAUSMAN TEST FOR CONVENTIONAL BANKS

\begin{tabular}{lcc|cc}
\hline \hline \multirow{2}{*}{ Model } & \multicolumn{2}{c|}{ Falaysia } & \multicolumn{2}{c}{ Bahrain } \\
\hline Model 1 & 30.4767 & 35.2646 & 16.6110 & 35.3095 \\
& $(0.0000)$ & $(0.0000)$ & $(0.0000)$ & $(0.0000)$ \\
Model 2 & 31.8614 & 5.0652 & 9.4153 & 19.3712 \\
& $(0.0000)$ & $(0.0000)$ & $(0.0000)$ & $(0.0222)$ \\
\hline \hline
\end{tabular}

TABLE V: HAUSMAN TEST FOR ISLAMIC BANKS

\begin{tabular}{lcc|cc}
\hline \hline & \multicolumn{2}{c|}{ Malaysia } & \multicolumn{2}{c}{ Bahrain } \\
Model & F-Statistic & Chi-Square & F-Statistic & Chi-Square \\
\hline Model 1 & 115.4056 & 9.1178 & 12.3064 & 11.3152 \\
& $(0.0000)$ & $(0.0000)$ & $(0.0000)$ & $(0.0000)$ \\
Model 2 & 7.3041 & 28.0232 & 19.4989 & 38.4447 \\
& $(0.0000)$ & $(0.0009)$ & $(0.0000)$ & $(0.0000)$ \\
\hline \hline
\end{tabular}

Table VII shows the results for a Fixed Effect for model 2. The value of $R^{2}$ shows that market risk is explained by the independent variables in which the overall estimation for all banks is good at above 80 percent. Value of adjusted $\mathrm{R}^{2}$ for Malaysia banks is 82 percent and Bahrain banks is 96 percent This shows that there is a difference between banks in Malaysia and Bahrain. Table VII highlights that all variables in this model are significant with market risk except for loan loss provision (LLP). The most significant variable in this model is Ratio of rate sensitive asset to rate sensitive liabilities (GAP). The results show that most of the banks are significant with market risk at 1 percent significance level. This suggests that that interest/profit rate is consistent with the GAP ratio in the annual report based on a one-year rate sensitivities of asset to liabilities. Regarding the result for Total Loan/Financing (TL), only banks in Bahrain are significant with the market risk. Both banks are positively significant. This result is also consistent with bank size (SIZE), whereas conventional banks in Malaysia have a negative relationship with market risk at 1 percent significant level but conventional banks in Bahrain have a positively significant at 10 percent significance level. Result from conventional banks in Malaysia is only consistent with [23].

\section{A. Regression Analysis on the effect of Performance}

This section discusses the results regarding the effect of liquidity and market determinants on bank performance in Malaysia and Bahrain banks which is presented in Table 8. The results show that all variables influence bank performance are significant except total loan/financing (TL) and total equity (TE). Both variable have to drop because it can produce a multicollinearity in regression. The value of $\mathrm{R}^{2}$ shows that ROE is explained by the independent variables in which the overall estimation for all banks is in the range of 48 to 62 percent. This shows that the best accountability for variations in ROE is found in Bahrain conventional bank with $R^{2}$ value of 62 percent. This model was examined by considering the ROE as the dependent variable and the deteminants of liquidity and market risk as a independent variables. Several variables emerge as significant determinants of bank performance, despite some differences in performance determinants between the two countries. The most significant determinants is capitalization (CAP) with the all banks have a negetive significant at 1 percent confident level. The negative signs of this coefficient suggest that the higher the capital of the banks the lower is the tendency for banks to perform. This result contradicts with [38] who find that the CAP are positively significant with performance.

TABLE VI: REGRESSION RESULTS FOR LIQUDITY RISK DETERMINANTS USING FIXED EFFECT (GLS)

\begin{tabular}{ccccc}
\hline \hline Variable & $\begin{array}{c}\text { Malaysia } \\
\text { Conventional }\end{array}$ & Islamic & $\begin{array}{c}\text { Bahrain } \\
\text { Conventional }\end{array}$ & Islamic \\
\hline Constant & 0.8732 & -0.0495 & 0.3036 & -0.1156 \\
& $(0.3350)^{* *}$ & $(0.0285)^{*}$ & $(0.0865)^{* * *}$ & $(1.5053)$ \\
IR & 0.0052 & -0.0108 & -0.0102 & 0.0164 \\
& $(0.0121)$ & $(0.0158)$ & $(0.0210)$ & $(0.0182)$ \\
DEPVOL & -0.1210 & -0.0213 & -0.1287 & $(0.0254$ \\
& $(0.0794)$ & $(0.0218)$ & $(0.1487)$ & -0.2690 \\
LVOL & -0.9140 & -0.0065 & -0.4438 & $(0.4419)$ \\
CAP & $(0.5135)^{*}$ & $(0.0101)$ & $(0.3373)$ & 0.6801 \\
& 1.5370 & 2.1572 & 3.5778 & $(0.2139)^{* * *}$ \\
LD & $(0.2235)^{* * *}$ & $(0.2325)^{* * *}$ & $(0.3785)^{* * *}$ & 0.2135 \\
& 0.1576 & 0.0255 & 0.3742 & $(2.0331)$ \\
GTA & $(0.0903)^{*}$ & $(0.0347)$ & $(0.1529)^{* *}$ & 0.3107 \\
& -0.0157 & 1.4493 & -0.0555 & $(0.1036)^{* * *}$ \\
MGT & $(0.0418)$ & $(0.5088)^{* * *}$ & $(0.0294)^{*}$ & -1.5373 \\
& 0.0006 & 0.0096 & 0.4163 & $(0.9138)^{*}$ \\
SIZE & $(0.0376)$ & $(0.0187)$ & $(0.1366)^{* * *}$ & 3.5561 \\
& 0.0172 & 1.0533 & -0.0037 & $(0.5472)^{* * *}$ \\
\hline$N$ & $(0.0436)$ & $(0.0445)^{* * *}$ & $(0.0097)$ & 162 \\
$R^{2}$ & 189 & 144 & 108 & 0.8940 \\
Adj. $R^{2}$ & 0.8025 & 0.9632 & 0.9539 & 0.8625 \\
$F$ & 0.7557 & 0.9531 & 0.9391 & 28.342 \\
DW & 17.1257 & 95.4597 & 64.292 & 0.0000 \\
\hline \hline
\end{tabular}

Note: Figure in parentheses is standard error value of the regression coefficient

$* * *, * *, *$ denotes significant level at $1 \%, 5 \%$ and $10 \%$ confidence level.

Another most significant determinats is non-interest income/income attributable to depositors (NONII) with all the banks have a positively significant at 1 percent. The possible explanation for this finding that bank with higher non-interest income will faced lower market risk and their performance are well managed. This result is contradictED 
with [13]. Both result also shows that there are significant performance. relationship between liquidity and market risk with

TABLE VII: REGRESSION RESULTS FOR MARKET RISK DETERMINANTS USING FIXED EFFECT (GLS)

\begin{tabular}{|c|c|c|c|c|}
\hline \multirow[b]{2}{*}{ Variable } & \multicolumn{2}{|c|}{ "Malaysia } & \multicolumn{2}{|c|}{ Bahrain } \\
\hline & Conventional & Islamic & Conventional & Islamic \\
\hline \multirow[t]{2}{*}{ Constant } & -5.5362 & 0.5108 & 0.8054 & 0.7172 \\
\hline & $(1.1818)^{* * *}$ & $(0.0597)^{* * *}$ & $(0.3408)^{* *}$ & $(0.2136)^{* * *}$ \\
\hline \multirow[t]{2}{*}{$\mathrm{TL}$} & -0.3684 & 0.1518 & 1.1852 & 0.8078 \\
\hline & $(0.2629)$ & $(0.2056)$ & $(0.3852)^{* * *}$ & $(0.4208)^{*}$ \\
\hline \multirow[t]{2}{*}{ LLP } & 0.0749 & 0.1101 & 7.6242 & 2.2664 \\
\hline & $(0.0930)$ & (3.7929) & $(6.3763)$ & (1.7827) \\
\hline \multirow[t]{2}{*}{ TE } & 0.2020 & 0.0565 & -0.4670 & -0.2714 \\
\hline & $(0.8774)$ & $(0.0187)^{* * *}$ & $(0.6753)$ & $(0.2016)$ \\
\hline \multirow[t]{2}{*}{ GAP } & -1.7548 & 6.6202 & 0.0859 & 1.6190 \\
\hline & $(0.2039) * * *$ & $(0.8284)^{* * * *}$ & $(0.1227)$ & $(0.2265)^{* * * *}$ \\
\hline \multirow[t]{2}{*}{ INTEXT } & 0.2004 & 0.0493 & -0.0040 & -0.0305 \\
\hline & $(0.0899)^{* *}$ & $(0.1033)$ & $(0.0471)$ & $(0.0182)^{*}$ \\
\hline \multirow[t]{2}{*}{ INV } & -0.6811 & -0.0018 & -0.6172 & -0.0071 \\
\hline & $(0.2638)^{* *}$ & $(0.0023)$ & $(0.2449)^{* *}$ & $(0.0667)$ \\
\hline \multirow[t]{2}{*}{ SIZE } & 0.7252 & -0.1511 & -0.0848 & 0.1726 \\
\hline & $(0.1587)^{* * *}$ & $(0.4649)$ & $(0.0449)^{*}$ & $(0.1698)$ \\
\hline \multirow[t]{2}{*}{ NONII } & 0.0112 & 0.0811 & -0.0059 & 0.0005 \\
\hline & $(0.0150)$ & $(0.0452)^{* *}$ & $(0.2905)$ & $(0.0023)$ \\
\hline \multirow[t]{2}{*}{ MGT } & 0.1440 & 0.1778 & -0.3580 & 0.0815 \\
\hline & $(0.1235)$ & $(0.2440)$ & $(0.2032)^{*}$ & $(0.3700)$ \\
\hline$N$ & 189 & 144 & 108 & 162 \\
\hline$R^{2}$ & 0.8604 & 0.8577 & 0.9531 & 0.9642 \\
\hline Adj. $R^{2}$ & 0.8187 & 0.8185 & 0.9354 & 0.9519 \\
\hline$F$ & 20.6784 & 21.8518 & 53.881 & 78.644 \\
\hline$P$ & 0.0000 & 0.0000 & 0.0000 & 0.0000 \\
\hline DW & 1.5352 & 1.5426 & 0.9701 & 1.9652 \\
\hline
\end{tabular}

Note: Figure in parentheses is standard error value of the regression coefficient $* * *, * *, *$ denotes significant level at $1 \%, 5 \%$ and $10 \%$ confidence level.

TABLE VIII: RESULT FOR PERFORMANCE DETERMINANTS

\begin{tabular}{|c|c|c|c|c|}
\hline & \multicolumn{2}{|c|}{ Malaysia } & \multicolumn{2}{|c|}{ Bahrain } \\
\hline & Conventional & Islamic & Conventional & Islamic \\
\hline \multirow[t]{2}{*}{ Constant } & 0.5075 & 0.0228 & -0.0019 & 0.0237 \\
\hline & $(0.0617)^{* * *}$ & $(0.0877)$ & $(0.0134)$ & $(0.3889)$ \\
\hline \multirow[t]{2}{*}{ IR } & -0.0132 & -0.1044 & -0.0276 & 0.0122 \\
\hline & $(0.0238)$ & $(0.0479)^{* *}$ & $(0.0083) * * *$ & $(0.0041)^{* * *}$ \\
\hline \multirow[t]{2}{*}{ DEPVOL } & 0.2156 & -0.0685 & 0.3640 & 0.3257 \\
\hline & $(0.0645)^{* * *}$ & $(0.0578)$ & $(0.0313)^{* * *}$ & $(0.0638)^{* * *}$ \\
\hline \multirow[t]{2}{*}{ LVOL } & -0.4133 & -0.1538 & -0.0484 & -0.4630 \\
\hline & $(0.3644)$ & $(0.0302)^{* * *}$ & $(0.0664)$ & $(0.1369)^{* * *}$ \\
\hline \multirow[t]{2}{*}{ CAP } & -3.7997 & -4.5446 & -0.4104 & -0.1178 \\
\hline & $(0.1987)^{* * *}$ & $(0.3118)^{* * *}$ & $(0.0541)^{* * *}$ & $(0.0299)^{* * * *}$ \\
\hline \multirow[t]{2}{*}{ LD } & 0.1140 & 0.3566 & 0.1023 & -0.0125 \\
\hline & $(0.0382)^{* * *}$ & $(0.0788)^{* * *}$ & $(0.0181)^{* * *}$ & $(0.5255)$ \\
\hline \multirow[t]{2}{*}{ GTA } & -0.0077 & 1.3948 & 0.0363 & -0.0589 \\
\hline & $(0.0536)$ & $(1.9001)$ & $(0.0057)^{* * *}$ & $(0.0271)^{* *}$ \\
\hline \multirow[t]{2}{*}{ MGT } & 0.0523 & 0.1370 & -0.0234 & -0.1801 \\
\hline & $(0.0446)$ & $(0.0707)^{*}$ & $(0.0296)$ & $(0.1150)$ \\
\hline \multirow[t]{2}{*}{ SIZE } & 0.0029 & $\mathbf{0 . 8 1 8 3}$ & -0.0101 & -0.1391 \\
\hline & $(0.0026) * * *$ & $(0.1256)^{* * *}$ & $(0.0055) *$ & $(0.0755)^{*}$ \\
\hline \multirow[t]{2}{*}{ LLP } & 0.0817 & 0.1047 & 0.3194 & 2.6196 \\
\hline & $(0.0404)^{* *}$ & $(1.2272)$ & $(0.6424)$ & $(0.8498)^{* * * *}$ \\
\hline \multirow[t]{2}{*}{ GAP } & 0.1101 & -0.4569 & -0.0670 & 0.3106 \\
\hline & $(0.0790)$ & $(0.0969) * * *$ & $(0.0198)^{* * *}$ & $(0.0692)^{* * * *}$ \\
\hline \multirow[t]{2}{*}{ INTEXT } & 0.4983 & 0.1410 & 0.0005 & -0.0054 \\
\hline & $(0.0364)^{* * *}$ & $(0.0308)^{* * *}$ & $(0.0050)$ & $(0.0027)^{* * *}$ \\
\hline \multirow[t]{2}{*}{ INV } & -0.2135 & -0.0005 & -0.0093 & 0.0605 \\
\hline & $(0.1175)^{*}$ & $(0.0010)$ & $(0.0366)$ & $(0.0550)$ \\
\hline \multirow[t]{2}{*}{ NONII } & 0.1244 & 0.1108 & 3.6144 & 0.0103 \\
\hline & $(0.0110)^{* * *}$ & $(0.0186)^{* * *}$ & $(0.0695)^{* * *}$ & $(0.0014) * * *$ \\
\hline$N$ & 189 & 144 & 108 & 162 \\
\hline$R^{2}$ & 0.6057 & 0.6022 & 0.6179 & 0.4804 \\
\hline $\mathrm{Rw}^{2}$ & 0.9097 & 0.8765 & 0.9912 & 0.8129 \\
\hline AIC & 270.9458 & 172.6435 & 135.7250 & 177.7594 \\
\hline $\mathrm{P}$ & 0.0000 & 0.0000 & 0.0000 & 0.0000 \\
\hline
\end{tabular}

Note: Figure in parentheses is standard error value of the regression coefficient

$* * *, * *, *$ denotes significant level at $1 \%, 5 \%$ and $10 \%$ confidence level.

Therefore, there are a different result from Malaysia and Bahrain, whereas bank size (SIZE) in Malaysia has a positive significant at 1 percent confidence level and Bahrain has negative significant at 10 percent confidence level. This shows that banks in Malaysia and Bahrain have a different in term of banks size and performance. The positive results 
consistence with [15], that larger banks will perform better because they have more diversified investment opportunities and also have a good management. [39] discovered that bank size is positively correlated with performance because of the lower interest rate to be charged to the borrowers the lesser the requirement for profits. However, Bahrain banks have a negative relationship between size and performance. Based on [38], growing size on profitability has been proved to be positive but Bahrain banks become extremely large, then the size will be negative because of bureaucratic issue and others reasons in the country. The negative results is consistence with [40] found that banks size has negative effect on performance. This strongly proves that the banking structure of large banks in Malaysia and Bahrain have a different regulation and supervisory even both countries are follow the guideline under Basel Committee on Bank Supervisory (BCBS) and Islamic Financial Services Board (IFSB) for conventional and Islamic banks. This shows that liquidity risk and market risk have a relationship with performance in term of bank size.

\section{CONCLUSION}

This paper has two main objectives; firstly to examine the determinants of liquidity and market risk of the banking system in Malaysia and Bahrain and secondly to analyze the effect of these determinants on bank performance. Eight factors as potential liquidity risk determinants and nine factors as the market risk determinants of banks are incorporated in three test models to reveal which of these factors are the major determinants of liquidity and market risks and also which of these determinants are contributors towards bank performance in both conventional and Islamic banking system. The major findings are summarized as follow: bank capitalization is the most significant variable for liquidity risk for all banks whereas GAP significantly determines market risk for Islamic banks but not for conventional banks. We find that bank size is important for the banking system because a larger bank can survive and perform better due to larger total asset. With the larger total asset, shows that bank have a potential to diversify their investment and it will give a good performance. This shows that conventional banks both in Malaysia and Bahrain are larger in terms of both size and total assets. The findings of this study can assist banks to comply with the principles for sound liquidity and market risk management and supervision developed by Basel Committee on Banking Supervision (BCBS) and Islamic Financial Services Board (IFSB) that provide detailed guidelines on the risk management and supervision. In fact, the effectiveness of liquidity and market risk management is very important in the banking system in order to increase their profitability and improve bank financial performance. An establishment of a comprehensive risk management in both banking systems should be a prerequisite as it contributes to the overall management of the banks. This paper only focuses on selected bank specific and macroeconomic indicators as risk determinants, for future research, it can be extended to include external factors that can affect bank liquidity and market risk. Besides that, to sustain the economic development through technical and vocational education training (TVET), the dialouge between government and TVET educator will enhance the knowledge and skill for student, partitioner and bank regulator.

\section{REFERENCES}

[1] T. F. Kolapo, R. K. Ayeni, and M. O. Oke, "Credit Risk and Commercial Banks' performance in Nigeria: A Panel Model Approach," Australian Journal of Business and Management Research, vol. 2, no. 2, pp. 31-42, 2012.

[2] N. Rozzani and R. A. Rahman, 2013, "Determinants of bank performance: Conventional versus Islamic," Jurnal Pengurusan, vol. 39, pp. $129-139$

[3] R. Moreno, "The changing nature of risks facing banks. In The banking system in emerging economies: How much progress has been made?" Bank for International Settlements, vol. 28, pp. 67-98, 2006.

[4] R. M. Said and M. H. Tumin, 2011, "Performance and financial ratios of commercial banks in Malaysia and China," International Review of Business Research Papers, vol. 7, no. 2, pp. 157-169.

[5] A. Ekinci, 2016, "The effect of credit and market risk on bank performance: Evidence from Turkey," International Journal of Economics and Financial Issues, vol. 6, no. 2, pp. 427-434.

[6] W. J. D. Haan, S. W. Sumner, and G. M. Yamashiro, 2007, "Bank loan portfolios and the monetary transmission mechanism," Journal of Monetary Economics, vol. 54, no. 3, pp. 904-924.

[7] S. Kasman, G. Vardar, and G. Tunç, "The impact of interest rate and exchange rate volatility on banks' stock returns and volatility: Evidence from Turkey," Economic Modelling, vol. 28, no. 3, pp. 1328-1334, 2011.

[8] D. Longworth, "Bank of Canada liquidity facilities: Past, Present, and future," Remarks by David Longworth at the C.D. Howe Institute, Toronto, February 2010.

[9] F. Sufian and R. R. Chong, "Determinants of bank profitability in a developing economy: Empirical evidence from the Philippines," Asian Academy of Management Journal of Accounting and Finance, vol. 4, no. 2, pp. 91-112, 2011.

[10] N. M. Ariffin, S. Archer, and R. A. A. Karim, "Risks in Islamic banks Evidence from empirical research," Journal of Banking Regulation, vol. 10, no. 2, pp. 153-163, 2009

[11] H. Al-Tamimi, A. Hussein, and H. Miniaoui, "Performance in the Gulf cooperation council countries," The International Journal of Business and Finance Research, vol. 9, no. 5, pp. 103-112.

[12] E. Hosseininassab, K. Yavari, N. Mehregan, and R. Khoshsima, "Effects of risk parameters (credit, operational, liquidity and market risk) on banking system efficiency (studying 15 top banks In Iran," Iranian Economic Review, vol. 17, no. 1, pp. 1-24, 2011.

[13] M. Aldoseri, Risk Exposure of Islamic Financial Institutions: Evidence from Gulf Co-operation Council countries NOVA, The University of Newcastle's Digital Repository, 2012.

[14] A. Siddiqui, "Financial contracts, risk and performance of Islamic banking," Managerial Finance, vol. 34, no. 10, pp. 680-694, 2008.

[15] S. Wasiuzzaman, and U. N. Gunasegavan, "Comparative study of the performance of Islamic and conventional banks: The case of Malaysia," Humanomics, vol. 29, no. 1, pp. 43-60, 2013.

[16] Z. A. Maaka, "The relationship between liquidity risk and financial performance of commercial banks in Kenya," Doctoral dissertation, University of Nairobi, 2013.

[17] H. A. Hussain and J. Al-Ajmi, "Risk management practices of conventional and Islamic banks in Bahrain," The Journal of Risk Finance, vol. 13, no. 3, pp. 215-239, 2012.

[18] M. K. Hassan and A. H. M. Bashir, "Determinants of Islamic banking profitability," presented at the 10th ERF Annual Conference, Morocco, 2003.

[19] V. Indriani, "The relationship between Islamic financing with risks and performance of commercial banks in Indonesia," Master Diss., University of Malaya, Malaysia, 2008.

[20] J. C. How, M. A. Karim, and P. Verhoeven, "Islamic financing and bank risks: The case of Malaysia," Thunderbird International Business Review, vol. 47, no. 1, pp. 75-94, 2005.

[21] S.A. Dennis and I. S. Suriawinata, 1996, "An empirical analysis of the determinants of australian commercial banks loans-to-deposit ratios," Working Paper, University of New South Wales.

[22] M. Sawada, 2010, "Liquidity risk and bank portfolio management in a financial system without deposit insurance: Empirical evidence from prewar Japan," International Review of Economics and Finance, vol. 19 , no. 3, pp. 392-406.

[23] M. F. Akhtar, K. Ali, and S. Sadaqat, Factors influencing the profitability of Islamic banks of Pakistan. International Research Journal of Finance and Economic, vol. 66, pp. 125-132, 2011. 
[24] M. F. Akhtar, K. Ali, and S. Sadaqat, Liquidity risk management: A comparative study between conventional and Islamic banks of Pakistan Interdisciplinary Journal of Research in Business, vol. 1, no. 1, pp. 35-44, 2011.

[25] A. B. Ishaq, A. Karim, A. Zaheer, and S. Ahmed, 2016, "Evaluating performance of commercial banks in Pakistan: 'An application of camel model'" Journal of Business and Financial Affairs, vol. 5, no. 1, pp. 2-30.

[26] M. Ramzan and M. I. Zafar, 2014, "Liquidity risk management in Islamic banks: A study of Islamic banks of Pakistan," Interdisciplinary Journal of Contemporary Research in Business, vol. 5, no. 12, pp. 199-216.

[27] P. Vodová, "Liquidity of Czech commercial banks and its determinants," International Journal of Mathematical Models and Methods in Applied Sciences, vol. 5, no. 6, pp. 1060-1067, 2011.

[28] N. Ahmed, M. F. Akhtar, and M. Usman, 2011, "Risk management practices and Islamic banks: An empirical investigation from Pakistan," Interdisciplinary Journal of Research in Business, vol. 1, no. 6, pp. 50-57.

[29] M. K. Hassan, "Capital market tests of risk exposure of loan sales activities of large US commercial banks," Quarterly Journal of Business and Economics, pp. 27-49, 1993.

[30] M. K. Hassan, "An empirical investigation of the existence of market discipline of off-balance sheet banking risk," International Review of Economics and Finance, vol. 3, no. 2, pp. 153-172, 1994.

[31] J. G. Gallo, V. P. Apilado, and J. W. Kolari, 1996, "Commercial bank mutual fund activities: Implications for bank risk and profitability," Journal of Banking and Finance, vol. 20, no. 10, pp. 1775-1791.

[32] N. H. Ahmad and M. Arif, "Key risk determinant of listed deposit-taking institutions in Malaysia," Malaysian Management Journal, vol. 8, no. 1, pp. 69-81, 2004.

[33] F. Gonzalez, "Bank regulation and risk-taking incentives: An international comparison of bank risk," Journal of Banking and Finance, vol. 29, no. 5, pp. 1153-1184, 2005.

[34] A. Rahman, M. Ibrahim, and A. K. M. Meera, "Lending structure and bank insolvency risk: A comparative study between the Islamic and conventional banks," Journal of Business and Policy Research, vol. 4, no. 2, pp. 189-211, 2009.

[35] L. Angbazo, "Commercial bank net interest margins, default risk, interest-rate risk, and off-balance sheet banking," Journal of Banking and Finance, vol. 21, no. 1, pp. 55-87, 1997.

[36] E. Milanova, "Market risk management in banks-model for analysis and assessment," Economic and Organzation Series, vol. 7, no. 4, pp. 395-410, 2010

[37] D. Gujarati, Basic Econometrics, New York: McGraw-Hill, 2008.

[38] P. P. Athanasoglou, S. N. Brissimis, and M. D. Delis, "Bank-specific, industry-specific and macroeconomic determinants of bank profitability," Journal of international financial Markets, Institutions and Money, vol. 18, no. 2, pp. 121-136, 2008.

[39] V. Flamini, M. L. Schumacher, and M. C. A. McDonald, 2009, The Determinants of Commercial Bank Profitability in Sub-Saharan Africa, no. 9-15, International Monetary Fund.

[40] Syafri, "Factors Affecting Bank Profitability in Indonesia," presented at the International Conference on Business and Management, Phuket, Thailand, 2012.

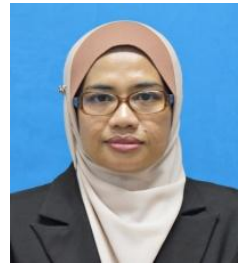

Norazwa A. Zolkifli was born on November 22, 1976 in Kuala Kangsar Perak, Malaysia. She received an undergraduate degree in business administration (finance) from University Utara Malaysia, master degree in technical dan vocational education from University Tun Hussien Onn and $\mathrm{PhD}$ in Islamic and Conventional banking and finance from University Kebangsaan Malaysia. Her research interest is risk management in banking system. She is working as a lecturer and a head of Commerce Department, Polytechnic Sultan Idris Shah, Selangor, Malaysia. She is involved in teaching and research for the last 12 years and represented her research in national and international conference.

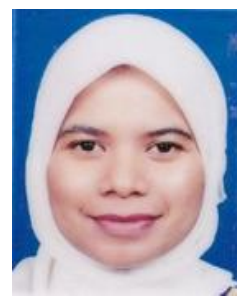

Khairul Jannah Samsudin was born on October 12, 1983 in Pulau Pinang, Malaysia. Her undergraduate studies were made up of diploma in banking and diploma in education from Universiti Teknologi Mara and Universiti Malaysia Sabah respectively, undergraduate degree which is known as BBA (Hons) Islamic banking that was also received from Universiti Teknologi Mara. Then she furthered her study in master level at INCEIF and had her Chartered in Islamic Finance Professional (CIFP). She is currently pursuing her study in $\mathrm{PhD}$ at Universiti Teknologi Mara in Islamic Contemporary Studies specializing in higher education waqf fund. She is also a lecturer at Commerce Department, Polytechnic Sultan Idris Shah, Selangor, Malaysia. She had written a few papers concentrating in Islamic finance education and higher education waqf fund.

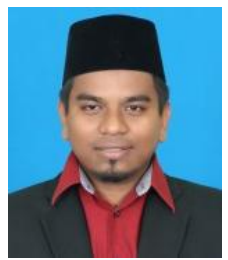

Mohd Burhan Bin Yusof was born on November 7 1985 in Sungai Petani Kedah, Malaysia. He obtained his bachelor of business administration with honors (finance) from Mara University of Technology (UiTM) and Masters Degree in Islamic Finance and Banking from University Utara Malaysia (UUM). Currently he is a certified Islamic financial planner (IFP) from Islamic Banking Institution of Malaysia (IBFIM). He is also an associate member of Financial Planning Association Malaysia (FPAM). At present, he is working as a lecturer in the Commerce Department of Polytechnic Sultan Idris Shah, Selangor, Malaysia. $\mathrm{He}$ is involved in teaching and research for the past 9 years and has presented his research in national and international conferences. 